\title{
Evidence of hydrothermal fluid flow in a hyperextended rifted margin: the case study of the Err nappe (SE Switzerland)
}

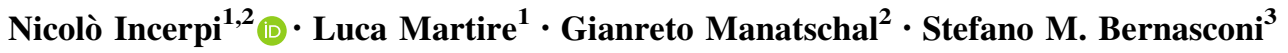

Received: 31 May 2016/Accepted: 7 December 2016/Published online: 7 January 2017

(C) Swiss Geological Society 2017

\begin{abstract}
This paper investigates hydrothermal fluid circulation in pre- and syn-tectonic sediments associated with detachments faults. The study area, located in the Err Nappe (SE-Switzerland), preserves a portion of the Adriatic distal margin. Two sites were studied in combining fieldwork, petrography, geochemistry and fluid inclusion analysis: the Piz Val Lunga and Fuorcla Cotschna areas. Both preserve relationships between a spectacularly exposed rift-related extensional detachment fault and its footwall and hangingwall that consist of extensional allochthons and syn- to posttectonic sediments. These areas register a complex fluid flow history characterized by dolomitization, de-dolomitization, calcite cementation, dolomite and quartz veining and diffuse silicification. Meso- and micro-scale observations allow defining two steps in fluid evolution, which are related to Jurassic rift activity. A first carbonate-rich event occurred before the exhumation of the granitic basement, and this was followed by a second event marked by a change in the fluid towards a silica-dominated chemistry. Homogenization temperatures of fluid inclusions (average $\mathrm{T}_{\mathrm{h}}=120-130{ }^{\circ} \mathrm{C}$ ), negative $\delta^{18} \mathrm{O}$ values and a radiogenic ${ }^{87} \mathrm{Sr} /{ }^{86} \mathrm{Sr}$ signatures of carbonate minerals support the hypothesis that both the pre-tectonic rocks constituting the allochthons and the syn-tectonic sediments overlying the detachment fault were crossed by a flux of over-pressured
\end{abstract}

Editorial handling: C. Sue and S. Schmid.

Nicolò Incerpi

nicolo.incerpi@unito.it

1 Dipartimento di Scienze della Terra, Università degli Studi di Torino, Via Valperga Caluso 35, 10125 Turin, Italy

2 EOST-IPGS, Université de Strasbourg, 1 Rue du Blessig, 67084 Strasbourg Cedex, France

3 Geological Institute, ETH Zurich, Sonneggstrasse 5, 8092 Zurich, Switzerland hydrothermal fluids originating from seawater that penetrated into the basement through fault and fracture systems. Field relationships show that this fluid circulation started latest in middle Early Jurassic time, when fault activity migrated from the proximal to the future distal margin. We propose that it evolved chemically as a result of the involvement of the granitic basement forming the footwall of the extensional detachment system. Hydrothermal activity continued until the Middle/Late Jurassic, when tectonic activity shifted outwards leading to the exhumation of mantle rocks. This paper provides an original contribution to better understand the complex evolution of hyperextended continental rift domains and to constrain their thermal regimes.

Keywords Hydrothermal fluids · Hyperextended rifted margin $\cdot$ Alpine Tethys $\cdot$ SE-Switzerland

\section{Introduction}

The access to high resolution seismic data and deep drill hole data from hyperextended rifted margins enabled the understanding of: (i) the architecture of such yet little explored domains (e.g. Iberia-Newfoundland, Peron-Pinvidic and Manatschal 2009; central segment of the South Atlantic, Contrucci et al. 2004; Moulin et al. 2005; Aslanian et al. 2009; Northwest Shelf off Australia, Karner and Driscoll 2000), and (ii) to propose new models about their tectono-stratigraphic evolution. These models show a poly-phase rift evolution that results in a complex final margin architecture: a proximal domain with a $30 \pm 5 \mathrm{~km}$-thick crust separated along necking zones from a thinned continental crust $(<10 \mathrm{~km})$ forming the hyperextended domains. The latter are separated from oceanic crust by an exhumed mantle domain. The thermal evolution of these distal domains is, however, very poorly constrained, although the presence of hydrothermal systems seems to play 
a key role in determining the heat fluxes (Cannat et al. 2009). A more detailed study of such systems is fundamental for reconstructing the diagenetic and thermal evolution of the sedimentary successions overlying these hyperextended margins. Since drill hole data are rare and in most cases proprietary, a valuable source of data comes from fossil margins preserved in collisional orogens. The best-studied examples are the Alpine Tethys margins preserved in the Alps. The study area described in this paper is located in the Lower Austroalpine Err nappe (SE-Switzerland), which samples remnants of the former most distal Adriatic rifted margin (Fig. 1). The Err nappe has been widely studied by several authors (e.g. Froitzheim and Eberli 1990; Manatschal and Nievergelt 1997; Manatschal 1999, Manatschal et al. 2000; Masini et al. 2011, 2012; Mohn et al. 2010). Its overall geological setting is very well constrained and the geometrical relationships related to the evolution of the margin are well exposed. This study shows that the Err nappe records a complex and long history of dolomitization, calcification and silicification that is related to Jurassic rifting. Crosscutting relationships indicate that these products refer to different steps of rifting, from the very early rifting to its final stages. The main aim of this paper is the characterization of the synextensional hydrothermal systems linked to rift-related extensional detachment faults and the overlying pre- to postrift sediments that are, respectively, Upper Triassic (NorianRhaetian) dolomites and Lower to Upper Jurassic sediments. Within this context, the goal is to describe and analyse different types of hydrothermal products such as cements, veins and replacement minerals that could testify fluid-rock interactions, the evolution of fluid composition through time, and the main pathways of these fluids.

\section{Geological setting}

The study area (Fig. 1) is located in SE Switzerland close to St. Moritz. It belongs to the Austroalpine nappe stack that overlies the Upper Penninic units formed by ophiolites. Former studies (e.g. Mohn et al. 2010) showed that these Alpine units preserve one of the most outstanding sections across a fossil magma-poor rifted margin. In particular in the Bernina and Err nappes remnants of the former Adriatic distal margin are spectacularly exposed. The most characteristic rift features of the distal margin are: the crustal thickness (reduced to less than $10 \mathrm{~km}$ ) and the occurrence of extensional detachment faults that separate exhumed crustal rocks in the footwall from extensional allochthons made of basement and pre-rift sediments in the hangingwall. Syn- to post-rift sediments onlap the detachment faults with an angle of less than $20^{\circ}-30^{\circ}$, which implies that these faults were exhumed at a low angle at the seafloor.

\section{The Adriatic distal margin: the Err detachment system}

The footwall is constituted of Paleozoic poly-metamorphic schists and gneisses intruded by the calcalkaline Albula granite (Cornelius 1932; Staub 1948; Von Quadt et al. 1994; Fig. 1). Since these rocks preserve primary stratigraphic contacts with Permo-Triassic sediments and volcanic rocks, they were part of the pre-rift upper crust before onset of rifting in Jurassic time. The Err detachment fault system corresponds to well-characterized brittle fault zones formed by tens of meter-thick damage zones constituted of characteristic green cataclasites and a core zone made of black fault gouges (Froitzheim and Manatschal 1996; Manatschal 1999). Where the detachment was exhumed at the seafloor it was partially eroded and overlain by syn- to post-rift sediments assessing a Jurassic age for this structure (Manatschal and Nievergelt, 1997). The hanging wall of the detachment system consists mainly of a poly-metamorphic basement in primary contacts with volcano-sedimentary sequences. Ladinian to Norian platform carbonates, Rhaetian limestones and shales, and the siliceous limestones of the Agnelli Fm., which are attributed to the Early Jurassic (Hettangian?early Pliensbachian based on ammonites; Dommergues et al. 2012) constitute the younger part of the pre-rift sediments. The Triassic succession, up to $500 \mathrm{~m}$ thick, is dismembered and never preserves the original thickness. As shown in Mohn et al. (2010) this is due to the onset of the major activity along the detachment faults giving rise to the so called "extensional allochthons" (Froitzheim and Manatschal 1996; Fig. 1c). The syn-rift sediments consist of complex gravitational to hemipelagic sedimentary deposits that occur either unconformably over the extensional allochthons or directly over tectonically exhumed basement (Handy et al. 1993; Handy 1996; Manatschal and Nievergelt 1997). Finger (1978) subdivided the syn-rift sediments into two formations, the Bardella and Saluver Fms. based on composition: the Bardella Fm. is made of reworked Triassic to Lower Jurassic carbonates (pre-rift rocks older than $185 \mathrm{Ma}$ ) whereas the Saluver Fm., subdivided by Masini et al. (2011) in a basal (A), intermediate (B) and upper (C) facies, includes mainly basement-derived material. Masini et al. (2011) defined two major time lines in the evolution of these hyperextended rift systems: (1) the top of the Agnelli Formation (TAF) that is dated with ammonites to the early Pliensbachian (about $185 \mathrm{Ma}$; Dommergues et al. 2012) and corresponds to the last pre-detachment sediments; and (2) the Radiolarian Cherts (RC) (Bathonian/Callovian, about $165 \mathrm{Ma}$; Bill et al. 2001) that correspond to the first post-rift sediments. The definition of 


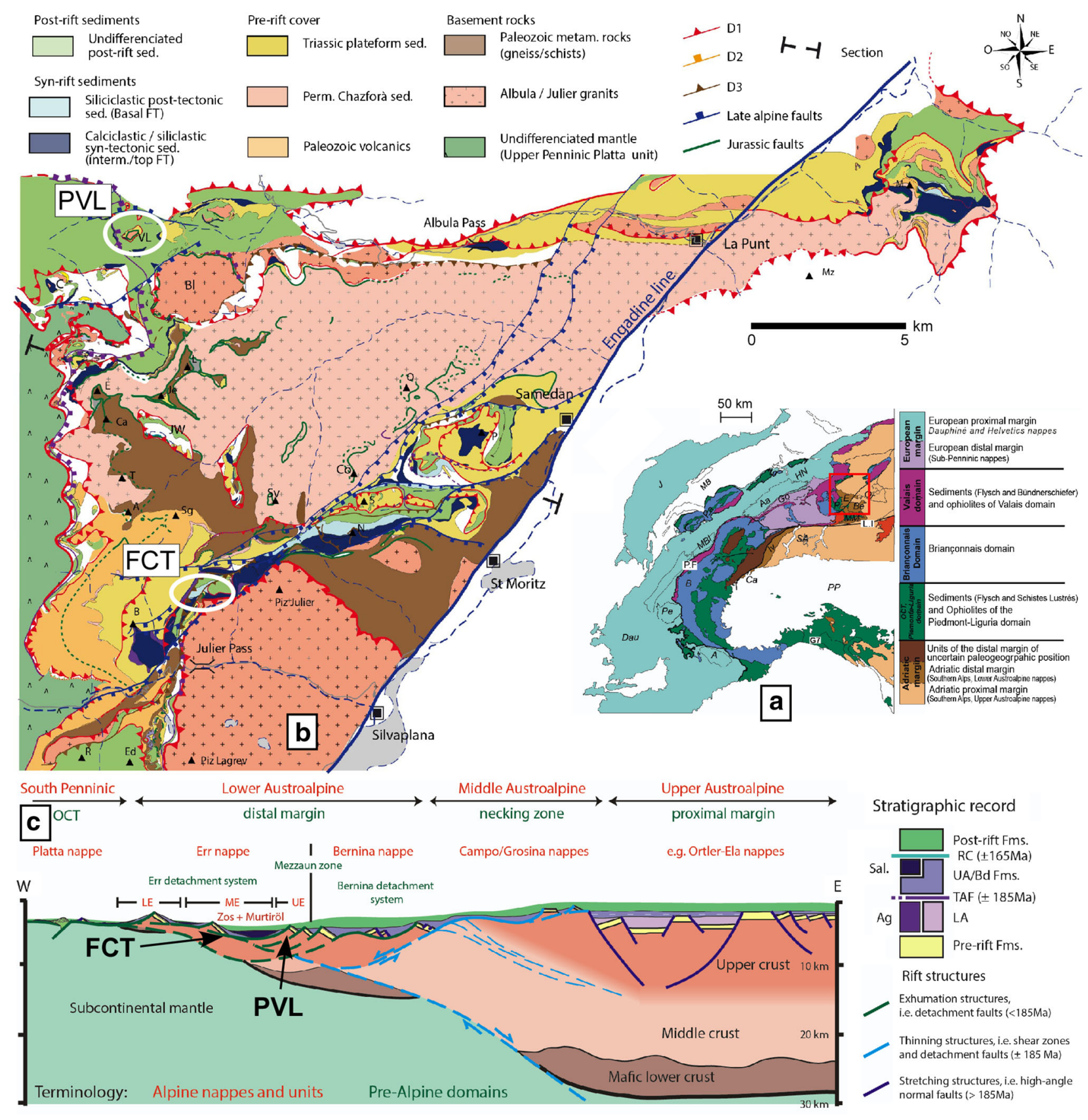

Fig. 1 a Tectonic map of the Alps modified after Schmid et al. (2004) and Mohn et al. (2010) with the location of study area (red square). b Geological map of the Err nappe (from Masini et al. 2012). The white circles in $\mathbf{b}$ mark the two studied areas. $P V L$ Piz Val Lunga, FCT Fuorcla Cotschna; c Restored section showing a section across the northwestern Adriatic rifted margin before onset of Alpine convergence in Late Cretaceous time (modified after Masini et al.

these two time lines enabled the authors to define the sedimentary sequences that were deposited from the onset of detachment faulting until the emplacement of first magmatic additions over exhumed mantle in the Platta oceanic domain.
2011). The section shows the distribution of the main paleogeographic domains of the margin (green terms) and refers to the major Alpine units (red terms). $O C T$ ocean continent transition, $L E$ lower Err unit, $M E$ middle Err unit, $U E$ upper Err unit, $A g$ Agnelli Fm., $L A$ lower Allgäu Fm., $U A$ upper Allgäu Fm., Bd Bardella Fm., Sal Saluver Fms., $R C$ radiolarian chert, TAF top of Agnelli Fm

\section{Materials and methods}

Detailed sampling has been performed in two different areas in the Err nappe: at Piz Val Lunga and at Fuorcla Cotschna (Fig. 1a). Petrographic studies on more than 120 
uncovered thin sections ( $30 \mu \mathrm{m}$ thick) were carried out by optical microscopy and cathodoluminescence (CL). CL observations were performed on polished thin sections using a CITL $8200 \mathrm{mk} 3$ equipment (operating conditions of about $17 \mathrm{kV}$ and $400 \mu \mathrm{A}$ ). In situ quantitative microprobe analyses were performed on carbon-coated thin sections with an energy dispersive X-ray spectroscopy (EDS) Energy 200 system and a Pentafet detector (Oxford Instruments) associated with a Cambridge Stereoscan S-360 scanning electron microscope (SEM). The operating conditions were $15 \mathrm{kV}$ of accelerating voltage, $1 \mathrm{nA}$ of probe current and $50 \mathrm{~s}$ counting time. Carbon and oxygen isotopic compositions of the carbonates were measured at the Stable Isotope Laboratory of the ETH Geological Institute, ETH Zurich, Switzerland using a Thermo Fisher Scientific GasBench II coupled to a Delta V mass spectrometer as described in detail in Breitenbach and Bernasconi (2011). The oxygen isotope composition of dolomite was calculated using the fractionation factor of Rosenbaum and Sheppard (1986). The isotopic ratios for carbon and oxygen are expressed as $\delta^{13} \mathrm{C}$ and $\delta^{18} \mathrm{O}$ per mil values relative to the VPDB (Vienna Pee Dee Belemnite) standard (precision $\pm 0.05 \%$ ). The analyses have been performed on micro-drilled powder of an as pure as possible single mineral phases. Fluid inclusions petrography has been studied at the University of Turin on bi-polished thin sections $(100 \mu \mathrm{m})$. Micro-thermometry of primary fluid inclusions assemblages on dolomite, calcite and quartz was performed using a Linkam THMSG600 heating-freezing stage coupled with an Olympus polarizing microscope $(100 \times$ objective), using the standard method described by Goldstein and Reynolds (1994). Sr isotope compositions were measured with a Finnigan MAT 262V multi-collector mass spectrometer at the CNR Istituto di Geoscienze e Georisorse in Pisa (Italy), running in dynamic mode. Conventional ion exchange methods were used for Sr separation from the matrix. Measured ${ }^{87} \mathrm{Sr} /{ }^{86} \mathrm{Sr}$ ratios were normalized to ${ }^{86} \mathrm{Sr} /{ }^{88} \mathrm{Sr}=0.1194$. During the collection of isotopic data replicate measurements of NIST SRM $987 \quad\left(\mathrm{SrCO}_{3}\right)$ standard yielded values of $0.710242 \pm 17$ (2 s, $\mathrm{N}=19)$.

\section{Stratigraphy and petrography}

\subsection{Piz Val Lunga}

The Piz Val Lunga section belongs to the Upper Err unit (Fig. 1c). Its western ridge exposes one of the best-preserved sections across a Jurassic extensional detachment (Fig. 2a). The footwall, now the summit of Piz Val Lunga, consists of Albula granite. The top of the basement is made of green cataclasites and black gouges (the latter containing mm- to dm-size clasts of granitic basement, green cataclasites, and Triassic dolostone), which represent the fault rocks of the Jurassic detachment fault. Stratigraphically above the detachment, the former hanging wall is constituted by an extensional allochthon made of Triassic dolomites (Fig. 2a-d) that are overlain by syn-rift sediments belonging to the Bardella Fm. (Fig. 2a, g). The prevailing lithotype of the allochthon is represented by grey dolostones characterized by an alternation of homogeneous, finely crystalline and thinly laminated beds showing shrinkage pores filled with dolomite and calcite cement. These distinctive features allow for assigning these rocks to the Upper Triassic peritidal dolomites of the Hauptdolomit Formation. Locally the allochthon is overlain by clastsupported breccias with angular to sub-rounded clasts of $\mathrm{cm}$ - to m-size. Clasts include: mudstones, grainstones with ooids whose cortices are partially dissolved and replaced by calcite spar; wackestones to packstones with peloids and benthic foraminifers (Glomospira, Triasina); wackestones with sponge spicules replaced by calcite spar (Fig. 3a); coarse crinoidal grainstones; packstones with peloids, crinoid and bivalve shell fragments, and sparse benthic foraminifers (Involutina). Clasts of cherts containing crinoids, ghosts of silicified peloids and patches of quartz and chalcedony, which represent void-filling silica cements, also occur. The matrix of the breccias consists of a packstone with peloids and bioclasts and sand-sized lithoclasts with the same composition and texture of the coarser clasts, and shows compactional features. The texture, composition and presence of biostratigraphically significant foraminifera allows for assigning these clasts to the Upper Triassic Kössen and part to the Lower Jurassic Agnelli Formations (Finger 1978; Furrer 1981). These breccias, by their composition and stratigraphic position, can be compared to the syn-rift Bardella Formation of Finger (1978) and Masini et al. (2011, 2012). Actually, the Hauptdolomit Formation appears almost completely brecciated with a variable degree of disruption of the rock and style of brecciation (Fig. 2). At one end, the rock is only crossed by a network of veins with minor displacement of fragments. These crackle breccias (Fig. 2c; Morrow 1982) transitionally pass to a breccia where clasts are significantly displaced but the fragments still fit one to another (mosaic breccias, Fig. 2b). Bedding and/or lamination is still recognizable although slightly offset. These rocks are locally crossed at a high angle by irregular bodies of polymict rubble breccias (Figs. 2d, 3b; Morrow 1982). In addition to the fenestral laminated finely crystalline dolomites, coarsely crystalline lithotypes also occur as clasts. All these breccias are matrix-free, clast-supported, and the voids among clasts are filled with a coarse, equant calcite spar that in cathodoluminescence (CL) is characterized by a clear oscillatory zoning (Fig. 3c). Moreover, CL and SEM- 

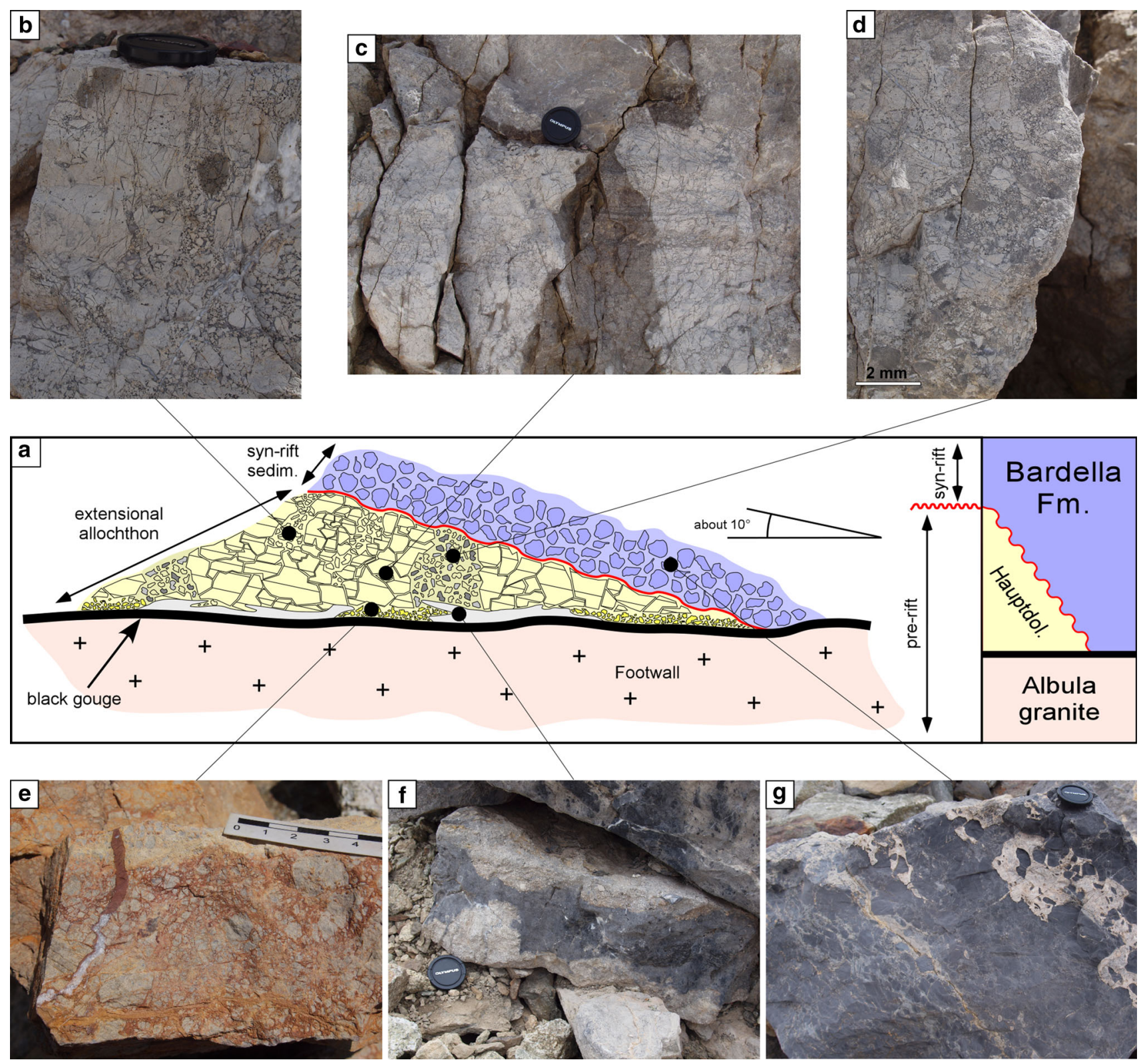

Fig. 2 a Schematic sketch, not to scale, representing the main features observed at Piz Val Lunga. The present day stratigraphy is upside down due to alpine tectonics. The extensional allochthon, made up of Hauptdolomit Fm., actually shows different textures: monomict mosaic (b) and crackle (c) breccias, which are locally crossed by polymict rubble breccias (d). e The base of the allochthon is characterized by clast-supported, monomict, poorly sorted breccias

BSE images show that the coarsely crystalline lithotypes in the breccia mainly consist of sparry calcite, with a moderate to bright yellow luminescence that selectively replaces discrete concentric zones within non-luminescent dolomite crystals (Fig. 3d-f). The entire rock body is crosscut by a system of calcite-filled veins mainly perpendicular to the bedding. Another type of breccia occurs close to the detachment fault. It is a clast-supported, monomict, poorly sorted breccia with sub-angular to sub- with subangular to subrounded clasts. Note the fracture geopetally filled with red sediment and white quartz cement. f Irregular dedolomitization (bluish color) affects the greyish dolomite breccias at the base of the allochthon. $g$ Partial silicification (whitish color) of the matrix of the Bardella Fm. breccias. Scales lens cap (about $6 \mathrm{~cm}$ in diameter)

rounded clasts which do not exceed $5-10 \mathrm{~cm}$ and a yellowish to reddish matrix. Clasts are composed of dolostones with variable crystal size (Fig. 2e). CL allows distinguishing clasts with very dull luminescence from the brightly luminescing finely crystalline calcite matrix, and thus, to observe that clasts may be as small as a few tens of microns (Fig. 3g, h). The breccias are crosscut by mmwide fissures with complex fills that include fine-grained sediment, locally laminated, and quartz (Figs. 2e, 3i, 1). 

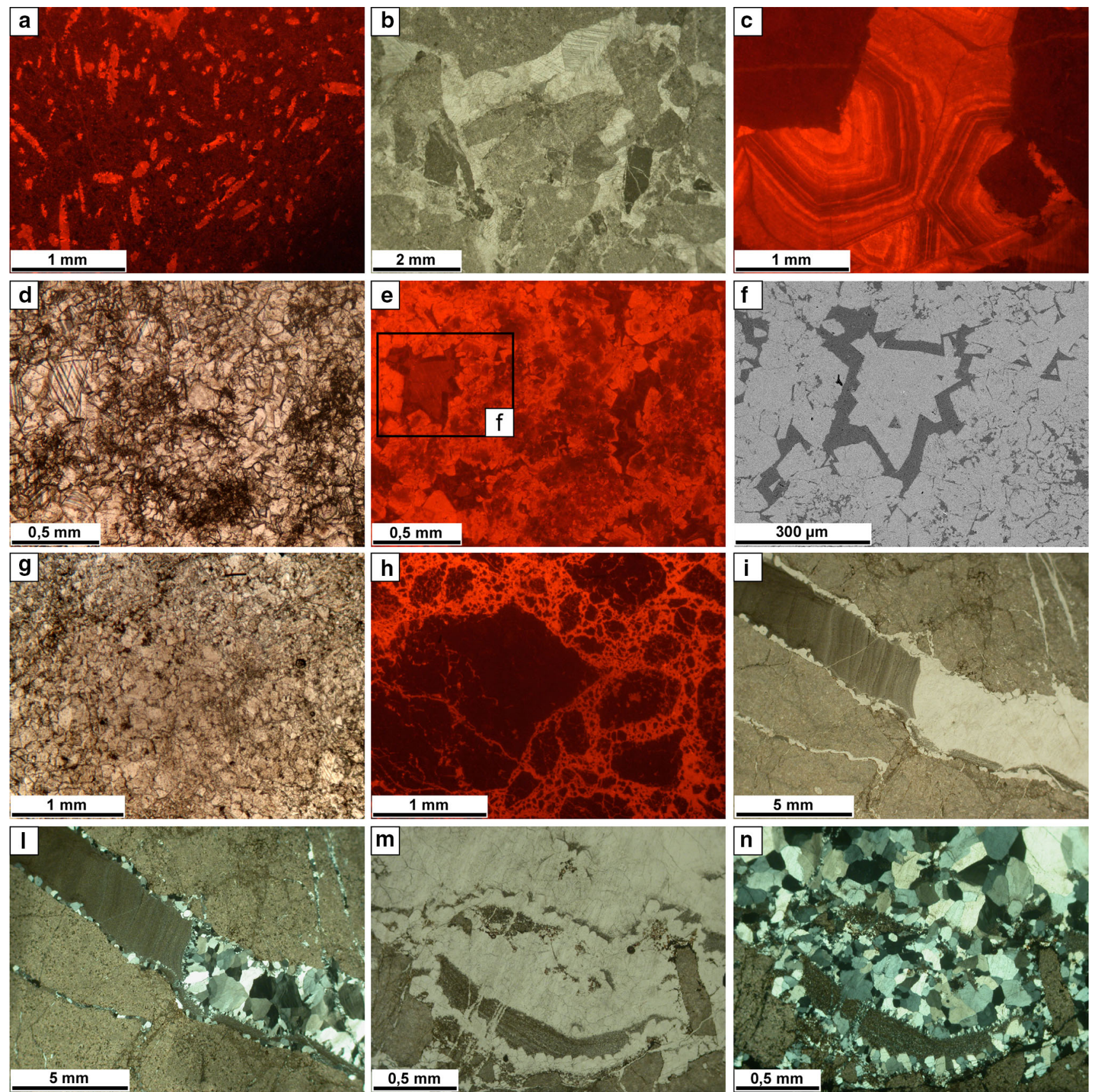

Fig. 3 Photomicrographs of pre-tectonic sediments at Piz Val Lunga. a Cathodoluminescence (CL) image of a clast in the Bardella Fm. made of wackestones with sponge spicules replaced by brightly luminescent calcite spar. b Transmitted-light (TL) and (c) CL images of polymict rubble breccia cemented by coarse equant calcite spar which shows oscillatory zoning. $\mathbf{d}$ TL, e CL and f SEM-BSE images of former coarsely, crystalline, dull luminescent dolomite, dark grey in SEM-BSE, largely replaced by sparry calcite, which shows a moderate to bright yellow CL and is light grey in SEM-BSE. $g$ TL

The latter forms a thin rim of crystals on the edges of the fissure subsequently filled with sediment, and plugs the remaining voids with larger crystals. In larger veins, sediment and quartz cement rims alternate, with sediment

and $\mathbf{h}$ CL images of clast-supported, monomict, poorly sorted breccias with dull luminescent dolomite clasts in a finely crystalline calcite matrix. i TL and $\mathbf{l}$ crossed polarizers images of mm-large fissures within the clast-supported, monomict breccias $\mathbf{g}$ and $\mathbf{h}$ with complex fills including fine-grained sediment, locally laminated, and quartz cement. $\mathbf{m}$ TL and $\mathbf{n}$ crossed polarizers images of larger veins filled with quartz. Note thin sediment drapes geopetally overlying euhedral crystal terminations of quartz crystals

geopetally lying on quartz crystal terminations (Fig. 3m, n). Locally all these breccias show irregular, dm-sized portions where the brecciated structure is almost completely obliterated and the rock is fully calcitic (Fig. 2f). 
The latter, lastly, is affected by a patchy silicification, which gives rise to irregular, dm-large portions where the carbonate rock is replaced by a mosaic of fine-grained quartz. In some instances, the breccias are affected by a selective replacement of dolomite by calcite as described above, although to a lesser extent. Silicification also affects the breccias of the Bardella Fm. The degree of silicification is variable over short distances, from nearly complete, to restricted to the matrix among clasts (Fig. $2 \mathrm{~g}$ ), or to $\mathrm{mm}$ - to $\mathrm{cm}$-wide, irregular bands consisting of fine-grained quartz crystals or chalcedony.

\subsection{Fuorcla Cotschna}

The area of Fuorcla Cotschna, belonging to the Middle Err unit (Fig. 1c), preserves a quite complete section through a supra-detachment sedimentary basin (sensu Masini et al. 2011, 2012) filled with syn- to early post-rift sediments (Fig. 4a, b). Similar to the Piz Val Lunga area, a Jurassic detachment fault separates the granitic footwall, constituted by the Albula granite and poly-metamorphic basement rocks, from the hanging wall represented by a pre-rift extensional allochthon (Piz Bardella allochthon of Masini et al., 2011) and syn-rift sediments onlapping the detachment with a very gentle angle (Fig. 4a, b). Since it has not been possible to observe a continuous stratigraphic section of the hanging wall, two key sections have been considered to best reconstruct the architecture of the Fuorcla Cotschna area. In the first one (transect A in Fig. 4a), grey carbonate rocks occur, which texturally range from sucrosic, massive dolostones with crystals some 100's $\mu \mathrm{m}$ in size to laminated finely crystalline dolostones showing shrinkage pores filled with up to $1 \mathrm{~mm}$-large dolomite crystals cement. The rock shows a dull to moderate reddish orange CL whereas the cement appears concentrically zoned with alternations of thin bright to dull reddish orange zones (Fig. 5a, b). The laminated dolostones are locally alternated with marly layers rich in bivalve shells. These carbonate rocks, by their lithofacies, can be referred to the upper part of the Upper Triassic peritidal Hauptdolomit Formation close to the boundary with the Rhaetian Kössen Formation. They are crossed by a complex network of 100's micrometers- to few millimeterthick, randomly oriented fractures mainly filled with saddle dolomite (Figs. 4c, 5c, d) whose crystals reach 2-3 mm in size and are generally very dull in CL. On weathered outcrop surfaces, these veins are clearly identifiable because of a yellow to orange color. Locally, up to $1 \mathrm{~cm}$-thick veins occur with a more complex filling made of quartz and euhedral to subhedral albite crystals some 100's micrometres large associated with dolomite. Quartz crystals poikilotopically include carbonate grains, from minute particles less than $10 \mu \mathrm{m}$ large to euhedral dolomite crystals 100's micrometres large. Stratigraphically above the pre-rift sequence, even if the contact is not clearly shown, a sedimentary clast-supported breccia made up of carbonate clasts occurs. The clasts, mostly rounded and ranging from few centimeters to some decimeters in size, consist of Triassic carbonates belonging to the pre-rift sequence and are commonly crossed by the same kind of veins described above, which stop at the edge of the clasts. The entire rock mass is characterized by several sets of veins, up to some millimeters large, cemented by coarsely crystalline saddle dolomite, quartz and calcite. Since no basement-related clasts have been observed, this sedimentary body can be assigned to the syn-rift Bardella Formation (Masini et al 2011, 2012; Finger 1978; Fig. 4d). Higher up a different coarse-grained sedimentary sequence occurs. It consists of clast- to matrix-supported conglomerates with angular to rounded clasts. Carbonate clasts prevail but granitic basement-derived ones are also common. The matrix consists of a medium to very coarse sandstone rich in quartz and feldspar grains. Due to the presence of footwallrelated material and its stratigraphic position, this sequence has been interpreted as Saluver A Formation (Masini et al. 2011, 2012; Finger 1978; Fig. 4e). As in the Bardella Formation, carbonate clasts are commonly crossed by veins, which stop at the edge of the clasts (Fig. 5e). In some instances, these veins show a first isopachous rim of dolomite cement, $200 \mu \mathrm{m}$ thick, with a dull brown luminescence, followed by fibrous quartz, which documents a syn-kinematic growth (Fig. 5f, g). Millimeter-thick veins cemented by quartz and subordinated saddle dolomite crosscut the whole conglomerate (Fig. 5h). Microprobe analyses of the dolostones occurring in the allochthon and in the clasts within Bardella and Saluver Fms. show that on the whole the replacement dolomite and the pore-filling dolomite cement are very poor in, or completely free of, $\mathrm{Fe}$ whereas vein dolomite contains up to $2.0 \mathrm{~mol}^{2} \mathrm{FeCO}_{3}$.

The Fuorcla Cotschna area clearly shows the relationships between the granitic footwall, the detachment fault and the overlying basin-filling sediments (transect $\mathrm{B}$ in Fig. 4a). The footwall displays the same features already described in the Piz Val Lunga area. The detachment surface is overlain by a stratigraphic succession that starts with medium to coarse sandstone beds made up of basement-derived quartz and feldspar grains alternated with $\mathrm{cm}$-thick pelitic beds. This decimeter-thick interval passes upward into a plurimetric, clast-supported and roughly graded sedimentary breccia. In its basal part, the $\mathrm{cm}$ - to $\mathrm{dm}$-sized clasts are almost completely constituted by allochthon-derived carbonate rocks whilst the matrix is composed of a medium to coarse-grained quartz and feldspar sandstone. Both the basal sandstone and the overlying breccias show mm-thick sub-vertical injections of black fine-grained material, which is derived from the gouge that caps the exhumed granite. Moreover, the breccias are crosscut by a dense network of mm thick and some meters 

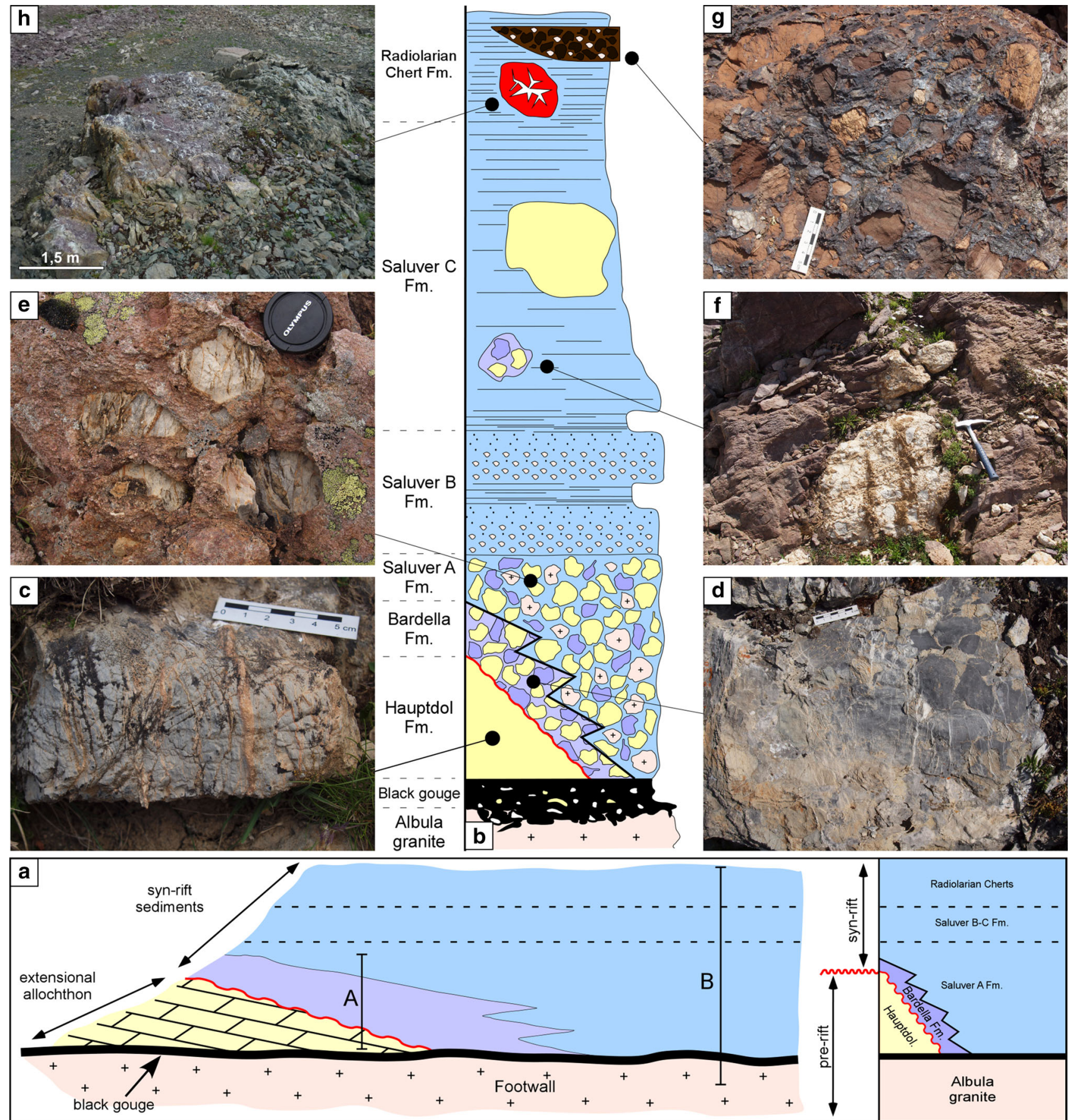

Fig. 4 a, b Schematic sketch and stratigraphic log, not to scale, of the Fuorcla Cotschna area based on transects $A$ and $B$ described in the text. c Massive dolostones belonging to the Hauptdolomit Fm. crossed by randomly oriented fractures filled with orange-yellow saddle dolomite. d Bardella Fm.: sedimentary clast-supported breccias made up of Triassic carbonate clasts. e Saluver A Fm.: clast- to matrixsupported conglomerates with carbonate and basement-derived clasts in a coarse sandy matrix. Note veins within clasts stopping at clast

long veins filled with quartz and saddle dolomite. The presence of basement-derived material constituting the matrix of the breccia allows for ascribing this body to the edges. f Decimeter-sized block of Bardella Fm. reworked in the red sandstones of the Saluver Fm. g Thick-bedded conglomerates constituted of carbonate and basement-derived clasts showing a peculiar brownish color of the carbonate clasts. The shiny black portion is silicified matrix. h Big "nodule" of chert within the lowermost part of Radiolarian Cherts crossed by an irregular network of quartz-filled fractures. Scales hammer $(33 \mathrm{~cm} \mathrm{long})$, lens cap (6 $\mathrm{cm}$ in diameter)

Saluver A Formation (Masini et al 2011, 2012; Finger 1978). Clasts are crosscut by dolomite- and quartz-filled veins that stop at the edge of clasts, showing the same 

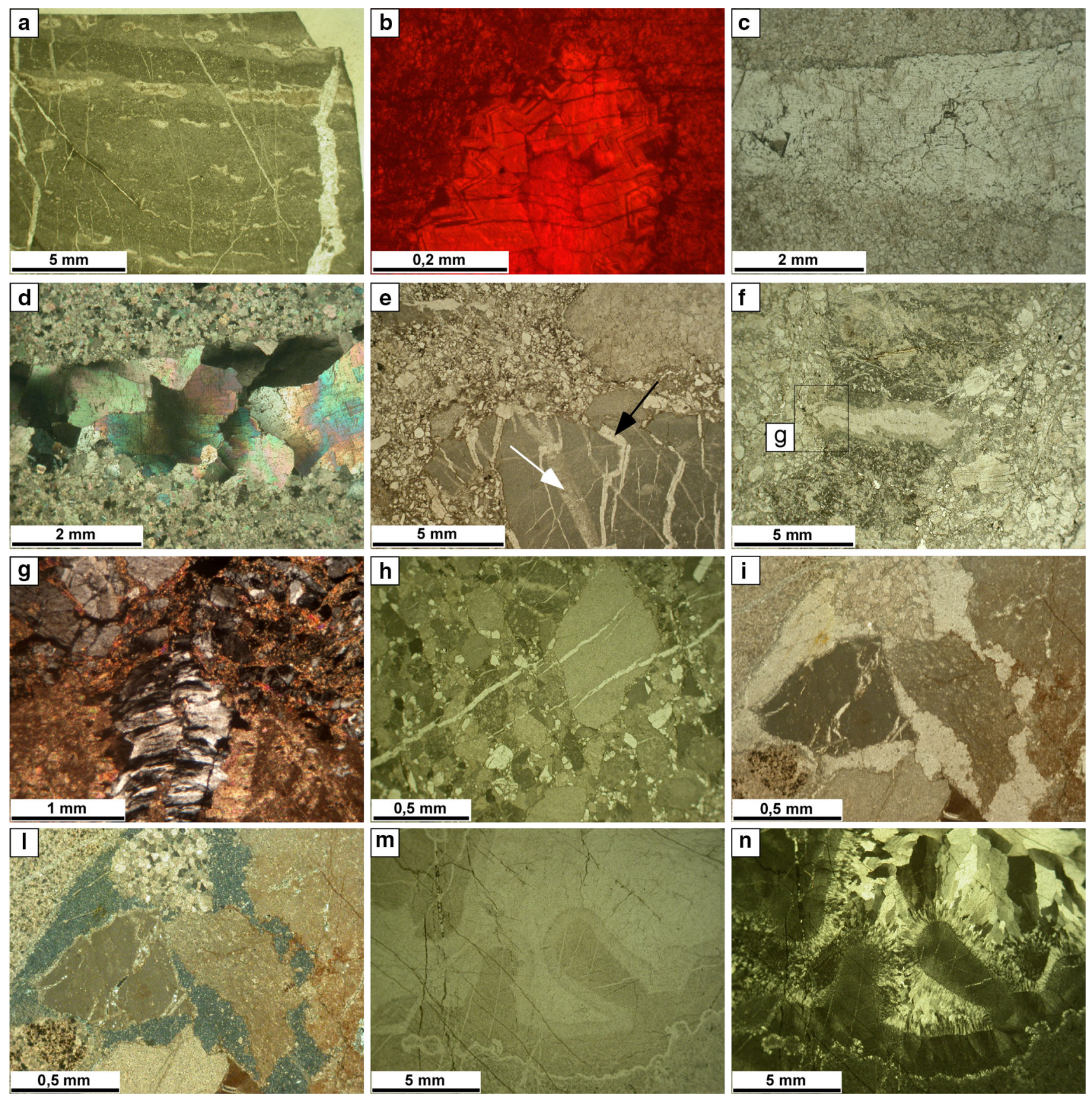

Fig. 5 Photomicrographs of pre- to post-tectonic sediments at Fuorcla Cotschna. a TL image of finely crystalline dolostone with shrinkage pores filled with dolomite cement. b CL detail of a shrinkage pore filled with concentrically zoned dolomite cement showing alternances of bright to dull reddish orange zones. $\mathbf{c}$ TL and d crossed polarizers images of a sucrosic dolostone of the Hauptdolomit Fm. crossed by coarse crystalline saddle dolomite vein. e TL image of carbonate clasts in the Bardella Fm. with quartz (black arrow) and dolomite (white arrow) veins which stop at the edge of the clasts. f TL and $\mathbf{g}$ crossed polarizers detail of multiphase filling of

features already described from Piz Val Lunga. Worth mentioning in the Saluver A unit is the presence of several meter-large blocks of Triassic dolostones in which $\mathrm{cm}$ - to vein within a clast in the Saluver Fm.: a first, $200 \mu \mathrm{m}$ thick, isopachous rim of dolomite is followed by a fibrous quartz infill. $\mathbf{h} \mathrm{TL}$ image of quartz veins crosscutting both clasts and matrix in the Saluver Fm. i TL and $\mathbf{l}$ crossed nicols images of polymict brownish conglomerate with a finely silicified matrix. m TL and $\mathbf{n}$ crossed nicols images of the large septarian-like nodule in Radiolarian Chert. Isopachous, botroidal chalcedony rims the cavity walls and is followed by a coarse mosaic of quartz crystals in the inner part of the cavities

dm-large grossly tabular bodies of crackle to mosaic breccias occur with a cement of coarse dull luminescent saddle dolomite, yellowish on outcrop. 
Up-section the sedimentary succession defines a thinning and fining upward trend. Conglomerates and breccias are progressively replaced by thin- to medium-bedded reddish turbidites, composed of siliciclastic sandstones and pelitic interbeds referred to the Saluver B and C units (Masini et al. 2011, 2012; Finger 1978). In the uppermost part of this succession, ghosts of radiolaria have been identified within reddish siliceous mudrocks and grey cherts, interbedded with sandstone beds, which should mark the onset of Radiolarian Chert deposition (Masini et al. 2011, 2012; Finger 1978). Nonetheless, much coarser deposits locally occur as scattered, several decimeter-sized blocks of carbonate breccias of the Bardella Formation (Fig. 4f) or thick to very thick-bedded conglomerates or breccias composed of variable amounts of basementderived or hanging wall derived carbonate clasts. One of these beds, a few meters above the first grey radiolarian cherts, is notable for the marked lenticular geometry and for the brownish color of most carbonate clasts (Fig. 4g). Microprobe analyses show that this color is due to variable degrees of $\mathrm{Fe}$ and $\mathrm{Mn}$ oxide staining. The whole Saluver Formation is crossed by veins filled with quartz and subordinate saddle dolomite and is affected by a localized but intense silicification. Such silification has been identified in (1) the blocks of Triassic dolostones, where irregular dmsized patches made of round-shaped clusters of quartz crystals up to $1 \mathrm{~mm}$ large occur; (2) the lenticular brownish breccia beds where the space among clasts is black, markedly weathers out, and consists of very fine-grained quartz (Figs. 4g, 5i, 1) in which dolomite rhombs, some 100 's $\mu \mathrm{m}$ long, are scattered; (3) the lowermost, grey, radiolarian chert beds, where a large "nodule" of chert, over $2 \mathrm{~m}$-long and about $1 \mathrm{~m}$ thick occurs (Fig. 4h); it is whitish at the outer edge and reddish in its inner part where it shows a crackle to mosaic breccia structure with white quartz veins up to over $1 \mathrm{~cm}$ large. The reddish chert consists of very fine-grained quartz whereas the veins are filled with isopachous, botryoidal chalcedony, which rims the vein walls, and a mosaic of quartz crystals (up to over $1 \mathrm{~mm}$ large) in the inner parts of the veins (Fig. $5 \mathrm{~m}, \mathrm{n}$ ). Interestingly, dm-sized clasts, showing the same features, are found in the lower, coarse, part of the thick turbiditic beds locally present in the Saluver C unit. Concentric, septarian-like fractures also occur in these clasts.

\section{Isotope geochemistry and fluid inclusion data}

\section{1 $\mathrm{O}$ and $\mathrm{C}$ isotope data}

$\mathrm{O}$ and $\mathrm{C}$ isotope analyses have been performed on calcite and dolomite in both the Fuorcla Cotschna and Piz Val Lunga sections. Analyzed dolomite includes Upper
Triassic samples of fine grained and sucrosic dolostones of the Hauptodolomit and Kössen Fms. and dolomite veins occurring within them, as well as clasts of these formations in breccias and in the Bardella Fm. The calcite samples correspond to sparry cement of mosaic breccias developed in the Hauptodolomit, to veins crosscutting the whole sedimentary succession and to the replacement of former dolomite. The results are shown in Fig. 6. All the data are characterized by slightly negative to positive $\delta^{13} \mathrm{C}$ values ( $-0.23 \%$ VPDB to $3.07 \%$. VPDB) and slightly to strongly negative $\delta^{18} \mathrm{O}$ values $(-1.01 \%$ VPDB to $-12.05 \%$ VPDB).

\section{2 $\mathrm{Sr}$ isotopes}

Two samples of replacement dolomite and one of a dolomite vein in the Hauptdolomit Fm. and one of calcite cement of breccias were analyzed. All these samples show ${ }^{87} \mathrm{Sr} /{ }^{86} \mathrm{Sr}$ values comprised between $0.708723 \pm 0.000011$ (Fuorcla Cotschna dolostone) and $0.709155 \pm 0.000007$ (Piz Val Lunga, calcite cement of breccia), which are markedly higher than expected for Triassic and Jurassic seawater (maximum values for Upper Triassic and Lower Jurassic 0.708000, McArthur et al. 2012; Fig. 7).

\subsection{Fluid inclusion results}

More than 80 fluid inclusions from 12 doubly polished sections have been measured to determine their homogenization temperatures. Useful primary fluid inclusions of (i.e. more than $2 \mu \mathrm{m}$ in diameter; Goldstein and Reynolds 1994) were found in the replacement dolomite and dolomite cement of fenestral pores in the Hauptdolomit Fm., which have been gathered because of their genetic relationships and represent set 1 , in the calcite cement of breccias representing set 2 , and in the calcite due to dedolomitization corresponding to set 3 . They are two-phase inclusions, liquid-rich with a vapor bubble, and vary in size from 2 to $10 \mu \mathrm{m}$. The very small size of inclusions hindered low-temperature runs aimed at determining the fluid composition. As shown in Fig. 8, set 1 homogenization temperatures range from 88 to $152{ }^{\circ} \mathrm{C}$ with the highest frequency between 120 and $130{ }^{\circ} \mathrm{C}$. The calcite cement (set 2) shows values from 77 to $203{ }^{\circ} \mathrm{C}$ with the highest frequency between 130 and $140{ }^{\circ} \mathrm{C}$ whereas de-dolomite calcite (set 3) ranges from 96 to $114{ }^{\circ} \mathrm{C}$.

\section{Discussion}

The aim of this study was to reconstruct composition and flow paths of fluids related to the formation of the Adriatic distal margin. We focused our investigation on the post- 


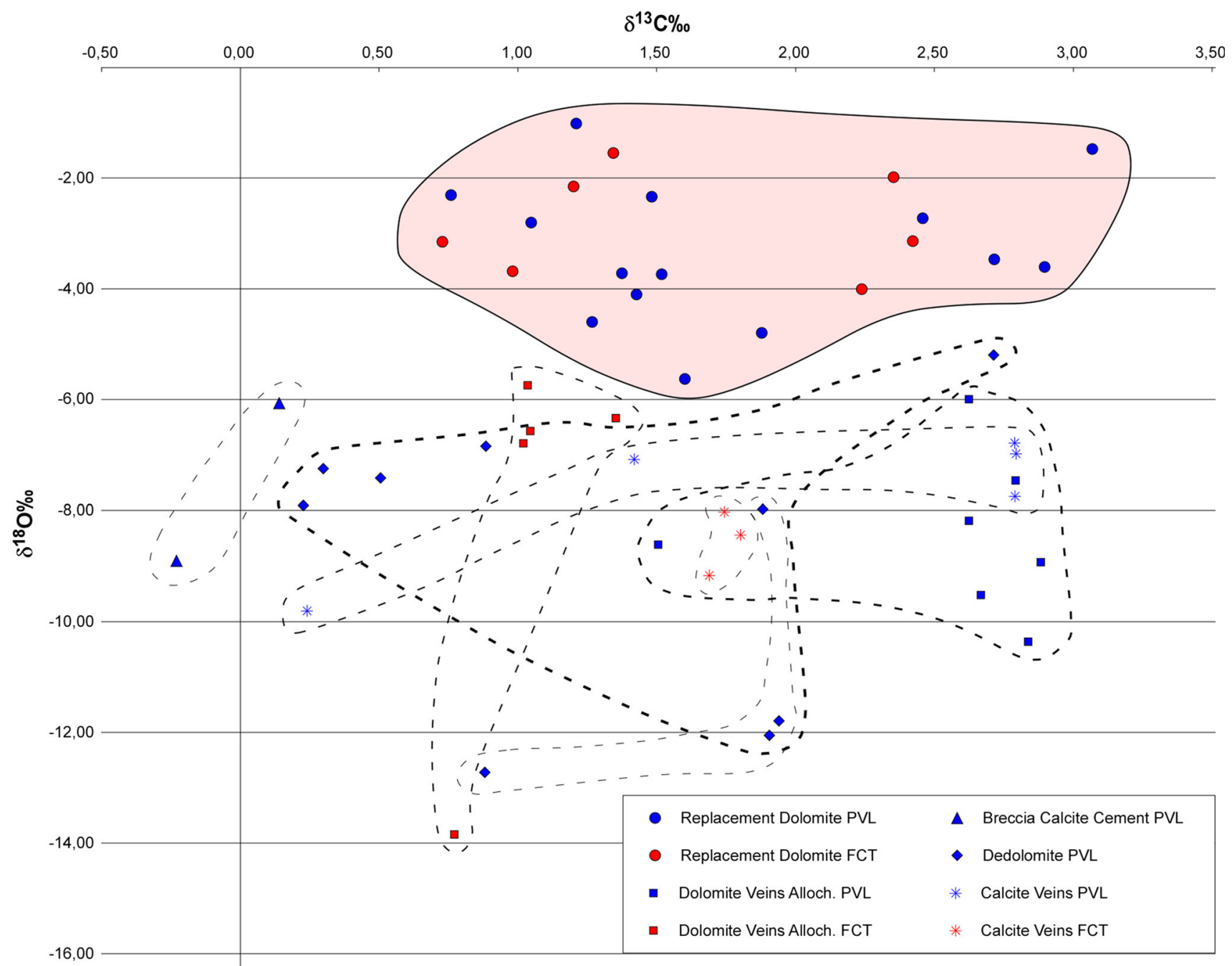

Fig. 6 Stable isotope data: $\delta^{18} \mathrm{O}$ versus $\delta^{13} \mathrm{C}$ cross plot for dolomite and calcite minerals from Piz Val Lunga (PVL) and Fuorcla Cotschna (FCT) areas; values are given relative to VPDB standard. The pink area corresponds to the first group of data described in the text

depositional modifications of the sedimentary rocks forming the allochthons and the syn-tectonic succession overlying the Err detachment system.

\subsection{Dolomite}

Two styles of dolomitization were distinguished: the first gave rise to finely crystalline dolostones with preservation of primary depositional textures; the second led to the formation of coarse crystalline sucrosic dolostones and zoned cements of fenestral pores (Fig. 5a, b). The preservation of CL zoning in the pore-filling dolomite cement clearly demonstrates that no subsequent recrystallization took place. The non-destructive fine-grained dolomite likely formed very early after deposition in a peritidal environment (Tucker and Wright 1990 and references therein). Conversely, the fabric-destructive coarse-grained (replacement dolomite and dolomite cements). The dashed lines encircle different mineral phases highlighting the difficulties to separate one group from another

replacement dolomite and the pore-filling cements are interpreted to have formed much later as the result of hydrothermal fluid flow. This is clearly documented by fluid inclusion micro-thermometry, $\mathrm{O}$ and $\mathrm{Sr}$ isotopes (see below).

\subsection{De-dolomitization}

De-dolomitization has been observed only at Piz Val Lunga within the Hauptdolomit Fm. Its occurrence is twofold: (1) at the base of the allochthon close to the detachment fault (Fig. 2f) it forms localized dm-sized patches and selective replacement of coarse dolomite crystals in the cataclasites (Fig. $3 \mathrm{~g}, \mathrm{~h}$ ); (2) in the overlying rubble breccias partly de-dolomitized clasts occur (Fig. 3d-f). Here, the presence of de-dolomitized clasts side by side with dolomitic ones shows that de- 


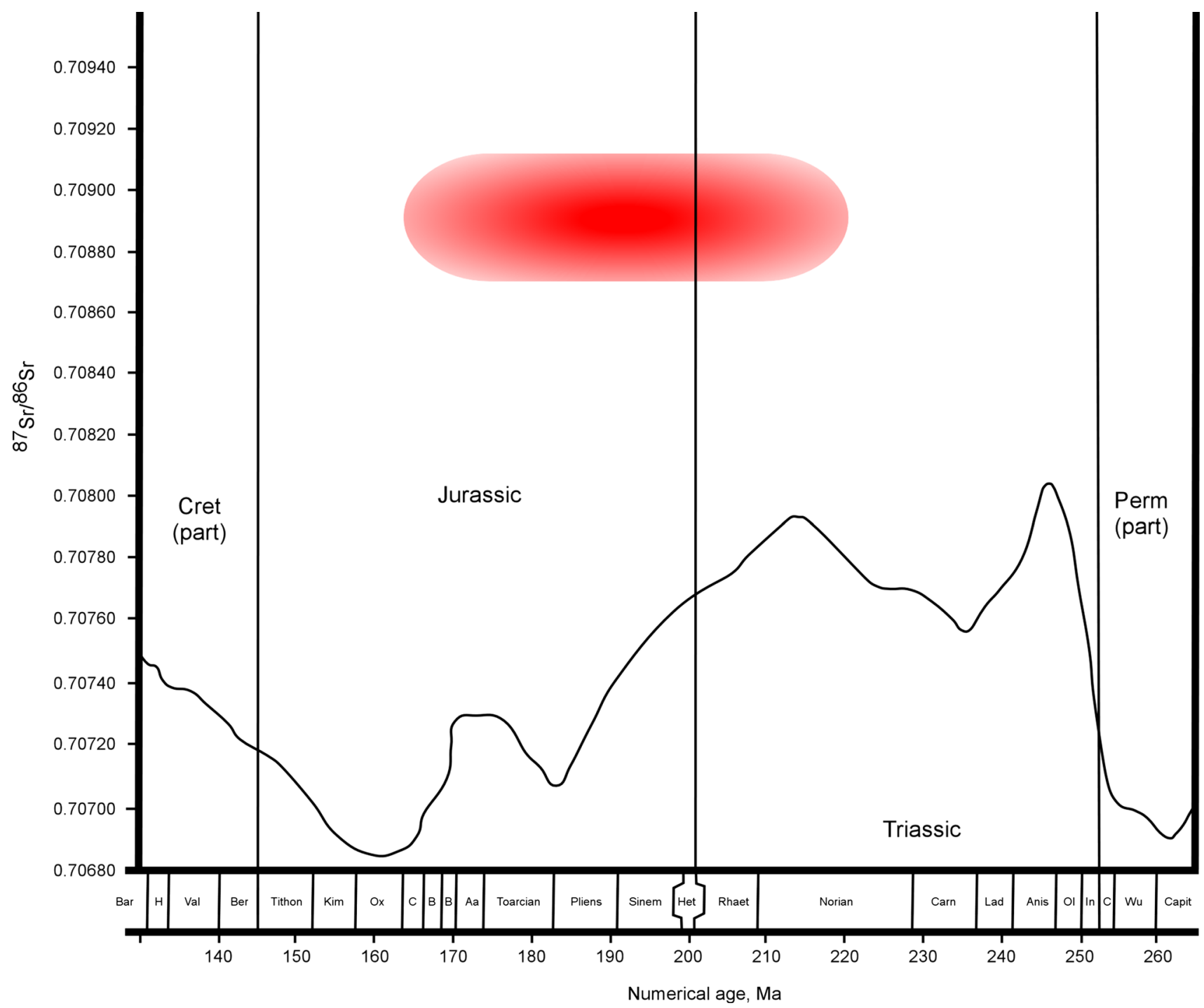

Fig. 7 Plot of ${ }^{87} \mathrm{Sr} /{ }^{86} \mathrm{Sr}$ values of replacement dolomite, dolomite vein, and calcite cement of breccias. The red area comprises the four samples analyzed in this work and ranges chronologically from the age of the dolomitized sediment (Norian) to the youngest possible age

dolomitization is not related to telogenetic processes associated with recent exposure at the surface but occurred before the formation of the breccias. This observation implies a change in the physico-chemical parameters of fluids compared to those responsible for the dolomitization described above.

\subsection{Breccias}

Leaving aside sedimentary breccias of the Bardella and Saluver Fms., other breccias are common at Piz Val Lunga in the Upper Triassic dolostone of the allochthon where they document different genetic processes. The dilational character of monogenic crackle and mosaic breccias (Fig. 2b, c), which are matrix-free and whose clasts mostly of dolomite veins (Middle Jurassic). The ${ }^{87} \mathrm{Sr} /{ }^{86} \mathrm{Sr}$ curve of latemiddle Permian to early Cretaceous seawater is reported to highlight the high, radiogenic values of the studied samples (modified after McArthur et al. 2012)

fit to each other, suggests mechanisms of in situ hydrofracturing. Polygenic, matrix-free rubble breccias (Figs. 2d, 3b), containing clasts from different beds of the original stratigraphic succession are interpreted as due to hydro-fracturing associated with some degree of vertical displacement of the clasts. A third type of carbonate breccia (Figs. 2e, 3g, h) characterized by the presence of a fine grained-matrix, very poor sorting, and somewhat rounded clasts, is interpreted to be related to cataclastic processes affecting the lower part of the allochthon just above the detachment fault. The absence of cataclasites and breccias formed by hydrofracturing at Fuorcla Cotschna is probably related to the much smaller thickness of the Piz Val Lunga allochthon compared to the allochthon situated west of Fuorcla Cotschna. At Piz Val Lunga the pre- 


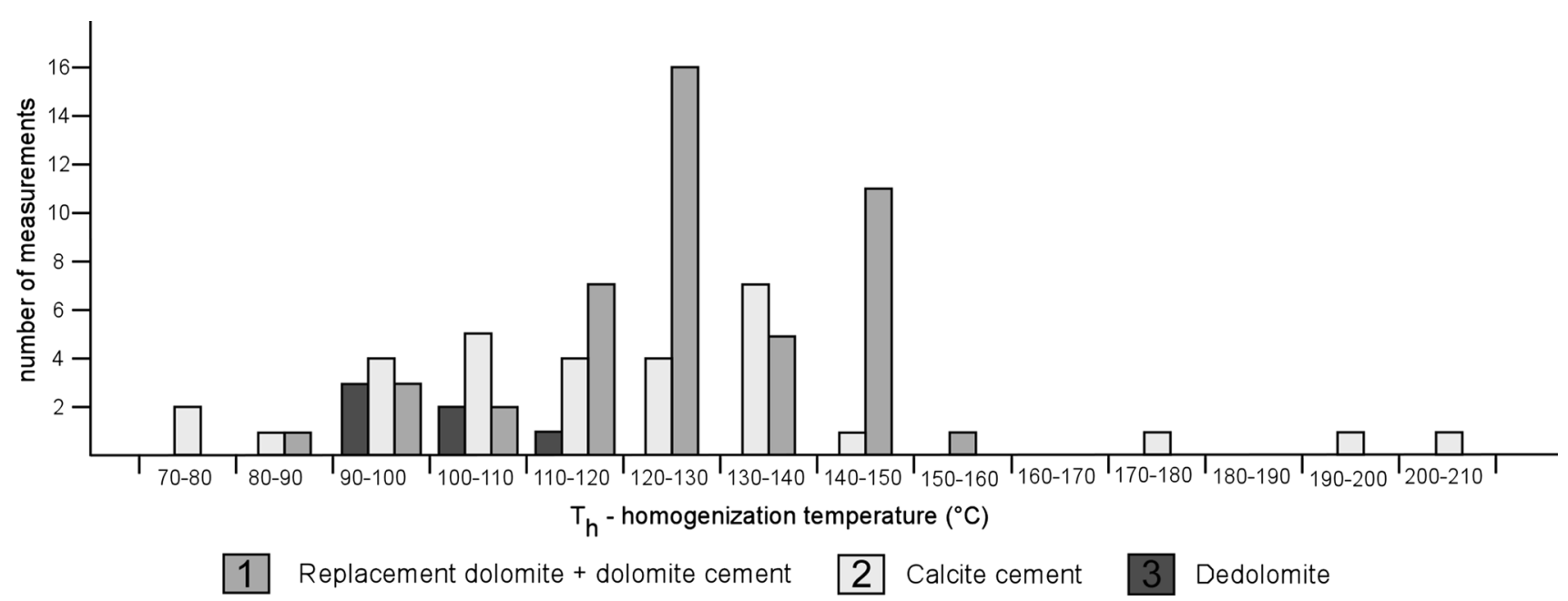

Fig. 8 Histogram of the homogenization temperatures for replacement dolomite and dolomite cement, calcite cement and de-dolomite

tectonic Triassic succession, comprised between the black gouge and the base of the Bardella Formation, is no more than a few tens of meters thick. The burial depth of the Triassic dolomites at Piz Val Lunga was thus very small and over pressured fluids flowing upwards along the detachment fault could easily overcome the internal strength of the overlying rocks inducing hydrofracturing. At Fuorcla Cotschna, conversely, the base of the allochthon is not exposed and consequently the cataclasites that presumably developed at the boundary with the footwall of the detachment cannot be observed. Furthermore, the hundreds of meters thick Triassic succession possibly hindered the formation of hydraulic breccias.

\subsection{Calcite cement}

Calcite cement mainly occurs at Piz Val Lunga associated with crackle, mosaic and rubble breccias, the latter including de-dolomitized clasts. The petrographic and CL features, coarse equant calcite spar with a distinct zoning, document a process of cement filling an open framework in static conditions (Fig. 3b, c). Given the relatively low abundance of calcite in the studied rocks, the comparable $\mathrm{CL}$ features and $\delta^{18} \mathrm{O}$ values in calcite cements and dedolomite (Fig. 6), we suggest that de-dolomitization and infilling of open pores in breccias are related to the same event of circulation of fluids supersaturated in calcite.

\subsection{Veins}

Veins are widespread and abundant throughout the Triassic-Jurassic sedimentary succession. Crosscutting relationships evidence that veining arises as a complex process which can be subdivided in two main stages, each one being polyphase. The veins within clasts of the Bardella and Saluver Fms. (Fig. 5e, f, g) document that a first stage of veining took place before reworking of the host rocks i.e. between the top of the Agnelli Formation (TAF) and the base of the Bardella Fm. (BBF), which most probably corresponds to a significant hiatus in sedimentation. Conversely, veins crosscutting the studied succession (Fig. 5h) show that subsequent stages of fracturing were recorded by breccias and conglomerates of the Bardella and Saluver Fms., respectively. The style of vein filling, mostly consisting of mosaics of non-oriented crystals, reflects a prevailing process of passive infill of open fractures in static conditions. Although much less frequent, syn-kinematic fibrous crystals, perpendicular to fracture walls, also do occur (Fig. 5f, g). Lastly, but importantly, the different mineralogy of the vein-filling phases (dolomite, calcite, quartz, albite) documents significant changes in fluid composition and consequently circulation paths. In fact, a trend through time has been detected from pre-BBF veins dominated by saddle dolomite to post-BBF veins, which are dominantly filled with quartz. This clearly points to an increasingly stronger interaction of fluids with basement rocks in which breakdown of feldspars delivered large amounts of silica to the fluids. Calcite-filled veins that crosscut all the stratigraphic succession and cannot be constrained chronologically could be related to Alpine orogenesis and were not studied in detail.

\subsection{Silicification}

The products of early diagenetic silicification are widespread in both sites and at different stratigraphic levels. Four types of cherts can be observed: (1) clasts of echinoderm-and sponge spicule-bearing grey cherts within the 
Bardella Fm. at Piz Val Lunga; (2) clasts of reddish cherts within the Saluver C Fm. at Fuorcla Cotschna commonly characterized by a brecciated, locally septarian-like, structure; (3) very large red chert nodules in the lower part of the Radiolarian Chert Fm. at Fuorcla Cotschna (Fig. 4h); and (4) silicified matrix of calciruditic beds in the Bardella Fm. at Piz Val Lunga and in the Radiolarian Chert Fm. at Fuorcla Cotschna (Fig. 5i, 1).

Type 1 cherts are easily referred to the Agnelli Fm. and result from early diagenesis of a sponge spicule opal A-rich succession taking place before its erosion and reworking as clasts. The reddish color of type 2 cherts conversely excludes provenance from the Agnelli Fm. and suggests a provenance from silicified clay-rich portions of the red turbidites of the Saluver C. The early, syn-depositional origin of type 2 and 3 cherts is documented by the reworking of type 2 cherts as clasts and by the transitional boundary of type 3 cherts with the encasing sediments, which indicate pre-compaction growth. The provenance of red cherts from the turbiditic Saluver C Fm., the relative scarcity of radiolarian-rich beds even in the Radiolarian Chert Fm. and the anomalous features of chert nodules (large size, dilational character, locally septarian-like, of brecciation with quartz-filled fractures; Fig. $5 \mathrm{~m}, \mathrm{n}$ ) show that biogenic opal could not be the source for such silicifications, which must have been extra-formational. Massive removal of silica from the quartzo-feldspatic footwall of the detachment seems the obvious and most likely source for silicification. It cannot be excluded that a contribution of silica came from serpentinization of mantle peridotites, which became exhumed to the seafloor in the Middle Jurassic and thereby increasingly affected by interaction with seawater (Pinto et al. 2015). Moreover, the brecciated textures document processes of hydraulic fracturing developed in these cherts, which were forming at very shallow burial depths, in a similar way to what happened in the brecciated Triassic dolostones at Piz Val Lunga. In this scenario, quartz veins (post-BBF; see Sect. 7.5) crossing subvertically the underlying succession could therefore represent the feeding system of $\mathrm{SiO}_{2}$-rich fluids flowing upward towards the sea floor. Here, the interaction with shallow buried, fine grained, highly porous sediments could give rise to chert nodules (chert type 3), which in turn could be exposed by erosion and re-sedimented as clasts, or to silicification of breccia matrixes (chert type 4).

\subsection{Fe-Mn oxide coating}

Different degrees of mineralization, from staining of the clast edges to intense replacement of the whole clast, point to a $\mathrm{Fe}-\mathrm{Mn}$ oxide precipitation before deposition of the calciruditic deposits occurring close to the Saluver C-Radiolarian cherts boundary at Fuorcla Cotschna (Fig. 4g).
This mineralization likely took place during a period of non-deposition and exposure of sediments at the seafloor. How far Fe and Mn were related to the exhumation of the mantle in more distal parts of the margin (OCT) (Pinto et al. 2015) should be supported by more detailed geochemical analyses, which are in progress.

\subsection{Fluid characteristics and flow paths}

While post-depositional processes such as dolomitization, veining, and silicification are observed at both sites, others are exclusive of only one section (cataclastic and hydrofracturing breccias, calcite cementation, de-dolomitization only at Piz Val Lunga, $\mathrm{Fe}-\mathrm{Mn}$ oxide coating only at Fuorcla Cotschna). Everywhere, however, the role of fluids appears to have been of primary importance in determining the final aspects of the rocks we presently observe. Isotope geochemistry and fluid inclusion micro-thermometry enable to constrain some characteristics of these fluids and their circulation patterns.

$\delta^{13} \mathrm{C}$ values of all the analyzed samples fall in the range of 0 to $+3 \%$ VPDB, which is characteristic of normal marine sedimentary carbonates and show no significant contribution of organic matter decomposition. $\delta^{18} \mathrm{O}$ values are all negative but show a quite widespread distribution from -1 to $-12 \%$ VPDB. Nonetheless, two main groups may be distinguished (Fig. 6). The first, with less ${ }^{18} \mathrm{O}$-depleted values mostly falling between -2 and $-4 \%$ VPDB, corresponds to Upper Triassic replacement dolomites and dolomite cements. The second group of values, basically comprised between -6 and $-10 \%$ VPDB, includes all the other samples (dolomite and calcite veins, calcite cements and de-dolomite), which largely overlap each other.

Samples of the first group (both finely and coarsely crystalline dolomites) show the least ${ }^{18} \mathrm{O}$-depleted values of the whole dataset which, however, are lower than those reported in present day settings where dolomite is forming and ranges from 0 to $+4 \%$ VPDB (Tucker and Wright 1990). The study of fluid inclusions indeed provides temperature constraints to these dolomites, with formation temperatures averaging $120-130{ }^{\circ} \mathrm{C}$ (Fig. 8). These dolomites already occur as clasts in the Bardella Fm. and thus they could not have been buried more than the cumulative thickness of the Kössen and Agnelli Formations, which does not exceed a few 100's m. Burial temperatures reached by Upper Triassic dolostones before middle Early Jurassic were thus certainly significantly lower than those documented by fluid inclusion micro-thermometry and a dolomitization event related to the upward advection of hydrothermal fluids is thus supported.

All the samples of the second group (dolomite and calcite veins, calcite cements and de-dolomite) plot in an area of more ${ }^{18} \mathrm{O}$-depleted values but the variability 
internal to each analyzed subgroup of samples (veins, cement etc.) is so large that it is impossible to separate it from the others on the basis of $\mathrm{O}$ or $\mathrm{C}$ isotope values alone.

Calculations of the isotope composition of fluids responsible for dolomite and calcite precipitation, made by applying the equation of Horita (2014) and Anderson and Arthur (1983), for dolomite and calcite, respectively, provide $\mathrm{O}$ isotope values for fluids from slightly to markedly positive $(+2$ to about $+12 \%$ SMOW). Such positive signature may be related to different processes such as evaporative enrichment (e.g. McKenzie 1981), clay mineral diagenesis (Dählmann and de Lange 2003; Hensen et al. 2007), and to the interaction with silicate minerals of siliciclastic and crystalline rocks (Clayton et al. 1966; Land and Prezbindowski 1981; Hitchon et al. 1990; Haeri-Ardakani et al. 2013). In the context of a distal continental margin the only reasonable source of fluids feeding the complex fracture-controlled circulation system was seawater. In particular, the stratigraphy of the studied sections, where deep-water sediments overlie basement rocks, leads to exclude the first two hypotheses. The highly radiogenic $\mathrm{Sr}$ isotope values of dolomite and calcite cements (Fig. 7), conversely, demonstrate a fundamental contribution by feldspars and thus support a circulation of fluids within the quartzo-feldspatic footwall of the extensional detachment system.

The quite wide range of variability of $\delta{ }^{18} \mathrm{O}$ values is suggested to depend on the characteristics of the flow paths: depth of circulation affects temperature whereas residence time of fluids in the basement rocks govern the degree of fluid-rock interaction and hence the enrichment in ${ }^{18} \mathrm{O}$. Moreover, low temperatures as measured in fluid inclusions and a lesser enrichment in ${ }^{18} \mathrm{O}$ could point to a mixing of fluids involved in more superficial circulation cells, such as along the extensional detachment fault, with those flowing up from deeper parts of the rock column.

\subsection{Evolutionary model}

The following scenario for the Triassic-Jurassic evolution of the Adriatic distal margin preserved in the Err domain at Piz Val Lunga and Fuorcla Cotschna sections may be suggested (Fig. 9). Two stages in the post-depositional diagenetic evolution can be distinguished: (a) the first affects the pre-tectonic successions (Hauptdolomit, Kössen, Agnelli Fms.) before their reworking and re-sedimentation as clasts in syn-tectonic sequences (Bardella and Saluver Fms.); (b) the second affects the whole succession (pre- and syn-tectonic sediments) although it is best recognized in syn-tectonic sediments. The first stage mainly involves fluids rich in carbonate and includes several processes such as dolomitization and dolomite cementation of pores, veining (formation of fractures and filling with saddle dolomite), and minor quartz precipitation in veins. At the base of the allochthon, intense friction between the basement and the overriding carbonate rock masses generated cataclasites within the latter and fluid circulation locally induced de-dolomitization. Fault-valve mechanisms along the detachment fault (Sibson 1992) may have caused a cyclic, abrupt release of overpressured fluids, which resulted in hydraulic fracturing of the overlying dolostones and filling of fractures or spaces among breccia clasts by saddle dolomite and calcite spar. Petrographic, isotopic and fluid inclusion features of dolomite and calcite show that they are of hydrothermal origin. The second stage of hydrothermal activity mainly involves silica, which occurs as vein fillings crosscutting the whole syn-tectonic succession (Bardella and Saluver Fms.). It occurs also as a replacement of still very soft and porous sediments developed, at very shallow burial depth, in the upper part of the syn-tectonic succession (Saluver B-C Fms.). There is therefore a clear trend in time from the first to the second stage from carbonate-dominated to silica-dominated processes. The first stage (post TAF, pre BBF i.e. middle to late Early Jurassic) may be related to the early phases of rifting in the distal margin when the crystalline basement was not exhumed yet and faults were not yet connected at depth. Seawater percolated through faults quite deeply, as $\mathrm{O}$ isotope data and fluid inclusion temperatures indicate (Figs. 6, 8), and interacted with basement rocks as $\mathrm{Sr}$ isotopes document (Fig. 7), but mainly reacted with the sedimentary succession and were saturated in carbonate. The second stage (post-BBF i.e. Middle Jurassic), occurring during and after deposition of the Bardella and Saluver Fms., and even during the first stages of Radiolarian Cherts deposition, documents important involvement of strongly fractured and altered crystalline basement rocks which were exhumed at the seafloor along extensional detachments faults, which delivered large amounts of $\mathrm{SiO}_{2}$ to the system with resulting precipitation of quartz.

\section{Conclusions}

The study of different hydrothermal products formed due to the long-lasting, multi-stage evolution of both the extensional allochthons and syn- to post-tectonic sediments in the Adriatic distal margin has been performed in two key outcrops of the Err nappe. The resulting scenario can be summarized as follows:

- A first stage, prior to the exhumation of the granitic basement, shows a predominant circulation of carbonate-rich fluids to which various processes affecting the pre-tectonic rocks are connected, such as dolomitization and dolomite cementation of pores, de- 


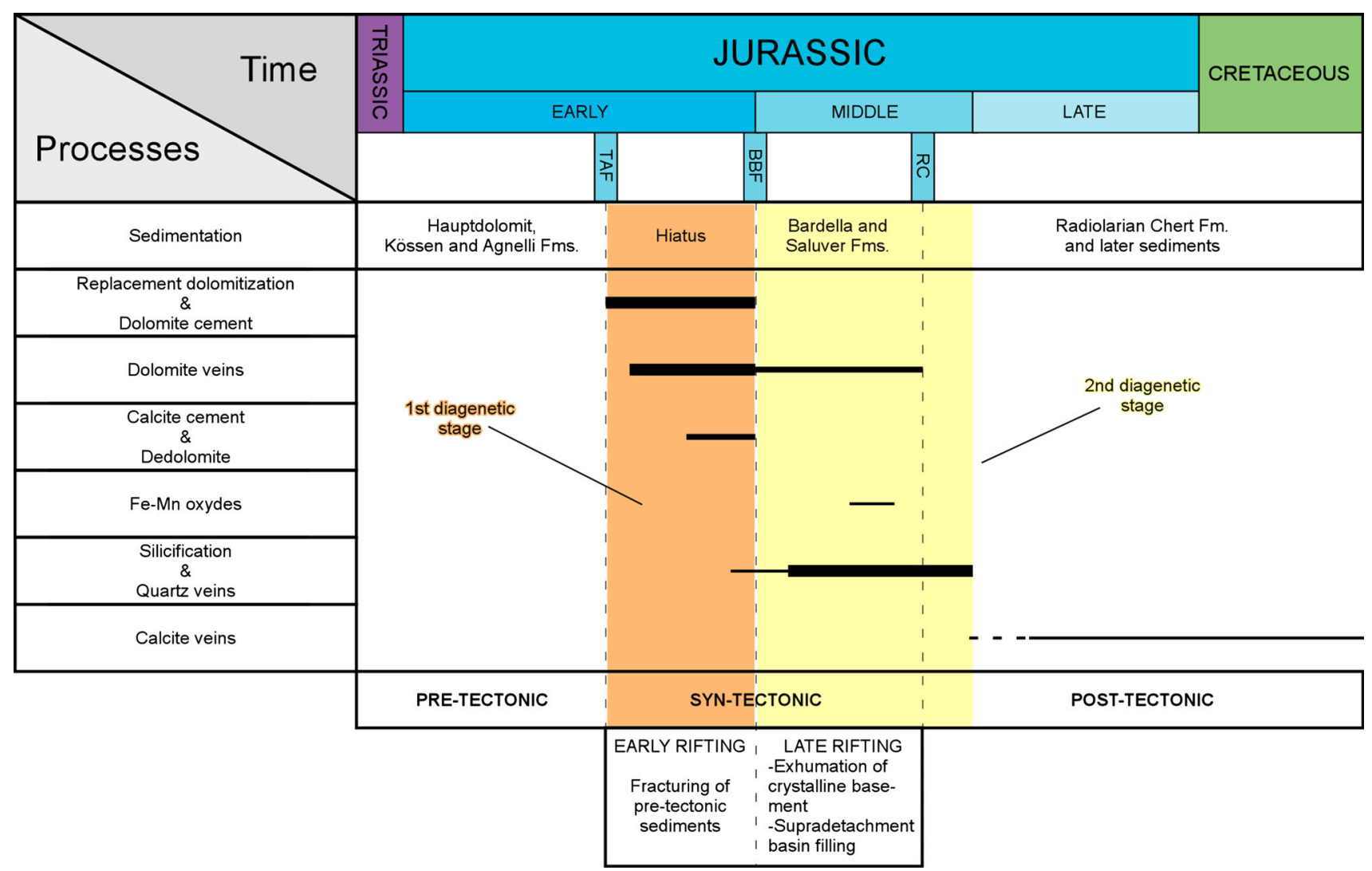

Fig. 9 Paragenetic sequence showing the relative timing of postdepositional processes and related products affecting the pre- to posttectonic sediments at Piz Val Lunga and Fuorcla Cotschna. The width

dolomitization, calcite cementation of breccias and formation of dolomite veins. This stage occurred in the middle to late Early Jurassic, after deposition of the Agnelli Fm. but before emplacement of the Bardella Fm. breccias which already include fragments of dolomitized and veined rocks;

- A second stage occurred during exhumation of the quartzo-feldspatic basement along extensional detachment faults. It implies a radical change in the chemistry of the hydrothermal system, from a carbonate-rich to a silica-dominated one. From this point onward, silicification and quartz veins represent the main features observed in the syn- to early post-tectonic sediments. Syn-depositional diagenetic modifications of post-tectonic Radiolarian Cherts, related to the flow of overpressured silica-rich fluids, testify how this circulation model lasted until the very final steps of distal margin evolution i.e. until Middle Jurassic time;

- Petrography combined with O, C, and Sr isotope analysis and fluid inclusion micro-thermometry allow to depict a complex sequence of events in which seawater had to flow in a deep and articulate system with a strong interaction with the basement rocks. Furthermore, the presence of Fe-Mn oxides, coating of the lines is qualitatively proportional to the magnitude of each process. TAF top of Agnelli Fm., $B B F$ base of Bardella Fm., $R C$ radiolarian cherts

clasts in the earliest post-tectonic succession, suggests a possible mantle-related origin for the late part of the fluid circulation system in the distal Adriatic margin (see also results of Pinto et al. 2015);

- The relatively high temperatures of precipitation of diagenetic products as inferred by fluid inclusion micro-thermometry coupled with shallow burial depths of formation (order of few tens to at most 100's m) strongly suggest anomalously high thermal gradients rather than very deep fluid circulation within the basement rocks of the extensional detachment footwall.

This study demonstrates the complexity of the evolution of hyperextended continental rift domains and, at the same time, highlights the importance of studying fossil analogues in order to better constrain and comprehend presentday passive margin features including post-depositional deformation and diagenetic modifications of sedimentary successions, fluid origin, composition and circulation pathways, and heat fluxes.

Acknowledgements The authors thank the two reviewers, M. LopezHorgue and P. Nievergelt, and the Journal Editor S. Schmid for a thorough revision of the text and the suggestions, which improved the manuscript. The research was financed by Petrobras S.A. and 
Università Italo-Francese/Université Franco-Italienne (Bando Vinci 2014, C2-190 to Nicolò Incerpi).

\section{References}

Anderson, T. F., \& Arthur, M. A. (1983). Stable isotopes of oxygen and carbon and their application to sedimentologic and paleoenvironmental problems. In M. A. Arthur, T. F. Anderson, I. R. Kaplan, J. Veizer, \& L. S. Land (Eds.), Stable isotopes in sedimentary geology (Vol. 10, pp. 1-151). SEPM Short Course: Columbia.

Aslanian, D., Moulin, M. Olivet, J.-L, Unternehr, P., Matias, L., Bache, F., Rabineau, M., Nouzé, H., Klingelhoefer, F., Contrucci, I., \& Labails, C., (2009). Brazilian and African passive margins of the Central Segment of the South Atlantic Ocean: Kinematic constraints. Tectonophysics (Special Issue: role of magmatism), 468, 98-112.

Bill, M., O’Dogherty, L., Guex, J., Baumgartner, P. O., \& Masson, H. (2001). Radiolarite ages in Alpine-Mediterranean Ophiolites; constrains on the oceanic spreading and the Tethys-Atlantic connection. Geological Society of America Bulletin, 113, 129-143.

Breitenbach, S. F. M., \& Bernasconi, S. M. (2011). Carbon and oxygen isotope analysis of small carbonate samples (20 to $100 \mu \mathrm{g}$ ) with a GasBench II preparation device. Rapid Communications in Mass Spectrometry, 25, 1910-1914.

Cannat, M., Manatschal, G., Sauter, D., \& Peron-Pinvidic, G. (2009). Assessing the conditions of continental breakup at magma-poor rifted margins: What can we learn from slow spreading midocean ridges? Compte Rendus Geoscience, 341, 406-427.

Clayton, R. N., Friedman, I., Graf, D. L., Mayeda, T. K., Meents, W. F., \& Shimps, N. F. (1966). The origin of saline formation waters: Isotopic composition. Journal of Geophysical Research, 71, 3869-3882.

Contrucci, I., Matias, L., Moulin, M., Géli, L., Klingelhoefer, F., Nouzé, H., et al. (2004). Deep structure of the west African continental margin (Congo, Zaire, Angola), between $5 \mathrm{~S}$ and $8 \mathrm{~S}$, from reflection/refraction seismic and gravity data. Geophysical Journal International, 158, 529-553.

Cornelius, H. P. (1932). Geologische Karte der Err-Juliergruppe 1:25000 (p. 115A). Schweiz: Geol. Komm., Spezialkarte.

Dählmann, A., \& de Lange, G. J. (2003). Fluid-sediment interactions at Eastern Mediterranean mud volcanoes: A stable isotope study from ODP Leg 160. Earth and Planetary Science Letters, 212, $377-391$

Dommergues, J., Meister, C., \& Manatschal, G. (2012). Early Jurassic ammonites from Bivio (Lower Austroalpine unit) and Ardez (Middle Penninic unit) areas: A biostratigraphic tool to date the rifting in the Eastern Swiss Alps. Revue de Paléobiologie, Genève, Vol. spéc. 11, 43-52.

Finger, W. (1978). Die Zone von Samedan (unterostalpine Decken, Graubünden) und ihre jurassischen Brekzien. PhD thesis, ETH Zürich, Zürich. doi:10.3929/ethz-a-000164017.

Froitzheim, N., \& Eberli, G. P. (1990). Extensional detachment faulting in the evolution of a Tethys passive continental margin, Eastern Alps. Switzerland. Geological Society of America Bullettin, 102(9), 1297-1308.

Froitzheim, N., \& Manatschal, G. (1996). Kinematics of Jurassic rifting, mantle exhumation, and passive-margin formation in the Austroalpine and Penninic nappes (eastern Switzerland). Geological Society of America Bulletin, 108, 1120-1133.

Furrer, H. (1981). Stratigraphie und Fazies der Trias-Jura-Grenzschichten in den oberostalpinen Decken Graubündens. Ph.D. dissertation, Univ. Zürich, Zürich.
Goldstein, R.H., \& Reynolds, T.J. (1994). Systematics of fluid inclusions in diagenetic minerals. SEPM Short Course 31, Tulsa, p. 199.

Haeri-Ardakani, O., Al-Aasm, I., \& Coniglio, M. (2013). Fracture mineralization and fluid flow evolution: An example from Ordovician-Devonian carbonates, southwestern Ontario, Canada. Geofluids, 13, 1-20.

Handy, M. R. (1996). The transition from passive to active margin tectonics; A case study from the zone of Samedan (Eastern Switzerland). Geologische Rundschau, 85(3), 832-851.

Handy, M. R., Herwegh, M., \& Regli, C. (1993). Tektonische Entwicklung Der Westlichen Zone Von Samedan (Oberhalbstein, Graubünden, Schweiz). Eclogae Geologicae Helvetiae, 86, 785-817.

Hensen, C., Nuzzo, M., Hornibrook, E., Pinheiro, L., Bock, B., Magalhaes, V., et al. (2007). Sources of mud volcano fluids in the Gulf of Cadiz-indications for hydrothermal imprint. Geochimica et Cosmochimica Acta, 71, 1232-1248.

Hitchon, B., Bachu, S., \& Underschulz, J. R. (1990). Regional subsurface hydrogeology, Peace River area, Alberta and British Columbia. Bulletin of Canadian Petroleum Geology, 38, 196-217.

Horita, J. (2014). Oxygen and carbon isotope fractionation in the system dolomite-water- $\mathrm{CO}_{2}$ to elevated temperatures. Geochimica et Cosmochimica Acta, 129, 111-124.

Karner, G. D., \& Driscoll, N. W. (2000). Style, timing and distribution of tectonic deformation across the Exmouth Plateau, northwest Australia, determined from stratal architecture and quantitative basin modeling. Geological Society of London Special Pubblication, 164, 271-311.

Land, L. S., \& Prezbindowski, D. R. (1981). The origin and evolution of saline formation waters, Lower Cretaceous carbonates, southcentral Texas and southern New Mexico. Hydrogeology Journal, $54,51-74$.

Manatschal, G. (1999). Fluid- and reaction-assisted low-angle normal faulting; Evidence from rift-related brittle fault rocks in the Alps (Err Nappe, Eastern Switzerland). Journal of Structural Geology, 21, 777-793.

Manatschal, G., Marquer, D., \& Frueh-Green, G. L. (2000). Channellized fluid flow and mass transfer along a rift-related detachment fault (Eastern Alps, southeast Switzerland). Geological Society of America Bullettin, 112, 21-33.

Manatschal, G., \& Nievergelt, P. (1997). A continent-ocean transition recorded in the Err and Platta nappes (Eastern Switzerland). Eclogae Geologicae Helvetiae, 90, 3-27.

Masini, E., Manatschal, G., Geoffroy, M., \& Unternehr, P. (2012). Anatomy and tectono-sedimentary evolution of a rift-related detachment system: The example of the Err detachment (central Alps, SE Switzerland). Geological Society of American Bulletin, 124, 1535-1551.

Masini, E., Manatschal, G., Mohn, G., Ghienne, J. F., \& Lafont, F. (2011). The tectono-sedimentary evolution of a supra-detachment rift basin at a deep-water magma-poor rifted margin: The example of the Samedan Basin preserved in the Err nappe in SE Switzerland. Basin Research, 23, 652-677.

McArthur, J. M., Howarth, R. J., \& Shields, G. A. (2012). Strontium isotope stratigraphy. In F. M. Gradstein, J. G. Ogg, M. Schmitz, \& G. Ogg (Eds.), The Geologic Time Scale 2012 (pp. 127-144). Amsterdam: Elsevier.

McKenzie, J. A. (1981). Holocene dolomitization of calcium carbonate sediments from the coastal sabkhas of Abu Dhabi, UAE: A stable isotope study. The Journal of Geology, 89, 185-198.

Mohn, G., Manatschal, G., Müntener, O., Beltrando, M., \& Masini, E. (2010). Unraveling the interaction between tectonic and sedimentary processes during lithospheric thinning in the Alpine 
Tethys margins. International Journal of Earth Sciences, 99, 75-101.

Morrow, D. W. (1982). Descriptive field classification of sedimentary and diagenetic breccias fabrics in carbonate rocks. Bulletin of Canadian Petroleum Geology, 30, 227-229.

Moulin, M., Aslanian, D., Olivet, J. L., Contrucci, I., Matias, L., Géli, L., et al. (2005). Geological constraints on the evolution of the Angolan margin based on reflection and refraction seismic data (ZaiAngo project). Geophysical Journal International, 162, 793-810.

Peron-Pinvidic, G., \& Manatschal, G. (2009). The final rifting evolution at deep magma-poor passive margins from IberiaNewfoundland: A new point of view. International Journal of Earth Sciences, 98, 1581-1597.

Pinto, V. H., Manatschal, G., Karpoff, A. M., \& Viana, A. (2015). Tracing mantle-reacted fluids in magma-poor rifted margin: The example of Alpine Tethyan rifted margin. Geochemistry, Geophysics, Geosystems, 16, 3271-3308.
Rosenbaum, J., \& Sheppard, S. M. (1986). An isotopic study of siderites, dolomites and ankerites at high temperatures. Geochimica et Cosmochimica Acta, 50, 1147-1150.

Schmid, S. M., Fuegenschuh, B., Kissling, E., \& Schuster, R. (2004). Tectonic map and overall architecture of the Alpine Orogen. Eclogae Geologicae Helvetiae, 97, 93-117.

Sibson, R. H. (1992). Implication of fault-valve behavior for rupture nucleation and recurrence. Tectonophysics, 211, 283-293.

Staub, R. (1948). Ueber den Bau der Gebirge zwischen Samedan und Julierpass und seine Beziehungen zum Falknis- un BerninaRaum (p. 93). Lief: Beiträge Geologische Karte Schweiz N.F.

Tucker, M. E., \& Wright, V. P. (1990). Carbonate sedimentology (p. 428). Oxford: Blackwell.

Von Quadt, A., Grünenfelder, M., \& Büchi, H. (1994). U-Pb zircon ages from igneous rocks of the Bernina nappe system (Grisons, Switzerland). Schweizerische Mineralogische und Petrographische Mitteilungen, 74, 373-382. 